\title{
Serving the underserved: the water-energy-food nexus in in socio-ecological production landscapes
}

\author{
M. Spiegelberg, S. Hoshino \& S. Hashimoto \\ Lab of Sustainable Rural Development, Kyoto University, Japan
}

\begin{abstract}
This paper sets out to show how Socio-Ecological Production Landscapes (SEPL) are the natural stage for the sustainable development of the Water-Energy-Food Nexus (WEF-Nexus) of rural inhabitants enduring insecure livelihoods and facing climatic changes.

Globally, about one billion people face water-insecurity, which is often interconnected with equally devastating deficiencies in energy- and food-security. The literature review revealed, that researchers, policy-makers and practitioners have shown that silo thinking, institutional mismatch, data gaps, the neglect of rural reality and a devaluation of local environmental knowledge block any efforts to improve the situation of either water-, energy- or food-security, and improved environmental governance and sustainable development in general. Long term approaches, integrative institutions coinciding with the natural systems, multilevel stakeholder participation and the maintenance and renewal of local, traditional techniques by diverse sets of knowledge have been identified as appropriate solutions to overcome those roadblocks. While the usual view of WEF-Nexus literature takes on a national and transboundary perspective, this on hand desk study argues that these solutions can be most effectively promoted on a SEPL scale. Despite rural exodus occurring in some regions, about $70 \%$ of the "bottom billion" still live in rural areas where their well-being and resilience depends strongly on the functioning of the local ecosystems and its services. Development efforts that recognize these dependencies and address them on the right level will result in sustainable and resilient livelihoods.

Keywords: water security, energy security, food security, landscape management, livelihood security, resilience, multilevel stakeholder participation, environmental governance, sustainable development, water-energy-food nexus.
\end{abstract}




\section{Introduction}

Throughout history, humans have settled near locations of safe water, energy and food supply. If the provision was not steady, roaming was practiced and with the developments over time techniques and technologies were invented to secure the provision of these basics of life over longer distances and/or in times of deficiency. And so began the story of altering ecosystems and whole landscapes. The human spirit pushed for ever more discoveries and alongside evolved governance structures and sciences systematizing those efforts. The organization of access and distribution of the given resources decided about the rise and fall of societies [1-3]. The complexity of the human-natural interaction kept increasing and reached its current global level of interconnectedness over all scales and spaces, a peak coined with the term anthropocene [4, 5]. Some view it as a possible breach of planetary [6] or at least regional boundaries [7]. At the same time, the world population is still growing and more than one billion people struggle daily to secure their livelihood [8-10]. In this world ca. 870 million people are undernourished [11], 1.3 billion people live without electricity access [12] and about 1 billion humans live without adequate access to water [13]. The projected global demand for water [14], energy [15] and food [16] steadily increases with population growth over the coming decades [17] and all of this happens in the light of changing climatic conditions around the globe [18].

The dimension and complexity of these challenges are not fully new. The different UN decades, the Rio-conventions and the development cooperation arrangements have tried one way or the other to eradicate poverty, end hunger and fix the human-environmental relations. Setting out from these challenges on the eve of the crafting of the sustainable development goals [19] the conducted literature review yielded three aspects: 1 ) roadblocks that have hindered so far the (more) successful implementation of efforts to secure livelihoods and to improve environmental governance of public resources; 2) what needs to be done to overcome these roadblocks; and 3) that the Water-Energy-Food Nexus (WEFNexus) approach on a Socio-Ecological Production Landscape (SEPL) scale is very suitable to do so. The aim of the paper is to contribute to the ongoing debates on the practical implementation of sustainable development, especially with focus on the one billion people underserved, to highlight the importance of multifunctional landscapes for securing livelihoods and to pin point an underrepresented field of research and policy, namely a local, bottom-up view, in the newly evolving policy- and research-field of WEF-Nexus.

\section{Roadblocks of sustainable development}

Throughout different scientific fields the literature study revealed two clusters of problems creating roadblocks on the way to sustainable development. One problem cluster is set around "silo thinking", while the other is summed up as "neglect of rural reality".

To approach the aforementioned challenges of livelihood security only from one perspective, disregarding the natural boundaries of ecosystems, horizontally 
through one single governance level or vertically along the lines of just one topic or scientific discipline is ultimately an undertaking failing to improve humanenvironmental relations overall and therefore not sustainable [14, 16, 20, 21]. Looking at the dimension and complexity of the mentioned challenges, hardly anyone can be expert in all of the mentioned topics at once [23]. However, coming with the nature of division of labor often also comes a division of views and institutional competencies. For example, policy reports about food or agriculture likely consider energy and water as mere input, while water might not be even mentioned as such in an energy assessment [10]. A further dimension of the silo thinking is the institutional mismatching, meaning that institutions ' responsibilities often do not coincide with the scale and/or properties of the natural system or common pool resource they are supposed to govern. The provisioning ecosystem services (e.g. food, timber) depending on intact biodiversity for example are largely provided on a local or landscape scale but often the governing institutions do not reflect this level [21]. So these various aspects of silo thinking might make the analysis of a problem at first easier and more comprehensible, yet in the long term create fragmented responsibilities, leading up to legal inconsistencies, false incentives, and disregard of externalities. As a consequence, the problems would not be solved overall and can contribute to already existing conflicts [7, 9, 21, 23-25].

In developing countries, the multipurpose utilization of water, energy and food from multiple sources is a reality in rural settings, but policies, research and development activities often neglect, oversee or ignore this [26-28]. One eminent result of this is a large knowledge and data gap on water, energy and food production and consumption especially for the livelihoods of the bottom billion with their variations in sources, sometimes as informal or illegal considered livelihood practices and reliance on ecosystem services [9, 14, 29-33]. For example, data about mechanical power technologies is, despite their importance in rural livelihood security basically non-existent [30]. Besides the data gap, there is also a disregard and devaluation of local ecological, traditional and indigenous knowledge, which have their roots in experience, inherit mostly the principles of sustainability and rely on the legacy of generations living at a given place [23, 34 40].

\section{Addressing rural realities and silo thinking}

The combination of growing demand for resources, their increasing depletion, and the problems created through silo thinking can create competition for water, energy and food between different user groups, exacerbating the exploitation and depletion of the ecosystems $[16,20,24,41]$. Dialogue, trust- and consensusbuilding are necessary to identify, create and utilize synergies and to manage socio-ecologic system (SES) and its ecosystem services effectively, efficiently and equitable in order to reduce conflictive dynamics. Integrative institutions play a fundamental role in this $[9,20,42-44]$. They are set up in accordance with the rural reality of multipurpose utilization of water, energy and food from multiple sources and the diversity of local stakeholders, and thus enhance the access to 
resources, goods and services. Furthermore they support the strengthening, innovation and climate proofing of local environmental knowledge. [28, 44, 4547] The maintenance, re-establishment and renewal of traditional methods and local knowledge improve the resilience of the people in "their" landscape and form a chance for proactive investment $[34,35,37,38,48]$. Stakeholder participation that is open for different sets of knowledge from multiple levels, yet close to the application of techniques, technologies and the utilization of water, energy and food and the provision of ecosystem services brings about meaningful, local data, improves social capital and results in locally applicable and therefore relevant activities that take the rural realities into account. This way ownership can be created and blind spots in policy and project design uncovered as already existing local coping strategies and adaptation efforts can be identified, included and/or improved [7, 16, 33, 37, 41, 43, 49-51].

\section{Cutting short with the WEF-Nexus and SEPL}

To address the challenges of the roughly one billion underserved and find ways of how to clear the roads to sustainable development, the Water-Energy-Food Nexus (WEF-Nexus) concept was presented in 2011 at the Bonn Nexus Conference, held in preparation of the Rio+20 Summit. This approach views its three elements not as separate fields but as one interdependent hub and therefore underlines the interlinkages, synergies and trade-offs between water, energy and food. In the WEF-Nexus publications the focus lies especially on three fields of global growth: world population, urban areas and the middle-class in transitioning countries with their ("westerly") consumer demands. The larger contexts and interlinkages of the above mentioned challenges of water-, energy- and food-security under changing climatic conditions are carved out and it has been widely acknowledged that the understanding and sustainable management of the WEF-Nexus is one of the keystones for establishing livelihood security, the provision of ecosystem services and increasing adaptive capacity. The literature underlines very well that the WEFNexus approach overcomes silo-thinking and its attached problems by bringing multiple stakeholders together in order to create dialogue and synergies. A strong emphasis lies on the international, watershed and transboundary scales, as well as on the rising economies of Asia with their growing megacities [1, 3, 6-10, 14, 29-31, 52-60].

Yet, because about $70 \%$ of the underserved billion live in rural areas where the resilience, the well-being, so the livelihood security around the WEF-Nexus depends strongly on the functioning of the local ecosystems and their regulating, provisioning, cultural and supporting services, it can be questioned, if this is actually the appropriate scale to recognize the rural realities, the importance of local knowledge and appropriate technologies, the coordination and cooperation among conflictive user groups and to ultimately increase the productivity of all three water, energy and food at once $[9,27,28,32,41,49,52,61]$. Therefore, a closer look is taken at the concept of Socio-Ecologic Production Landscape (SEPL). SEPLs are the result of humankinds' harmonious, gradual modification of all ecosystems in the pursuit for safe water, energy and food sources. They are 
complex multifunctional systems, a mosaic of different social-ecological subsystems consisting of biotic and abiotic components as well as anthropogenic structures that relate to each other. SEPLs are the locations of livelihood security and made up of a characteristic configuration of topography, vegetation, land use, and settlements determined by the social, physical, human, financial, and natural capital of the households. If left unmanaged, the system most likely collapses and seizes to provide the ecosystem services [24, 35, 36, 41, 62]. The WEF-Nexus is interwoven in this fabric across temporal, spatial and organizational scales and the SEPLs provisioning of ecosystem services is a determinant of rural livelihood security in developing countries. To pursue their livelihood security, which also includes water-, energy- and food security, people employ their capital-mix in activities to ultimately achieve well-being (physical, social and psychological), the security or increase of their capital and an improved resilience. The five different forms of household capital are interdependent among each other and the interaction of households and communities can be characterized by the various capital transactions between the people. If, how and when a capital is or can be transformed from one into another depends upon the traders' perceptions of the past, present and future status of the capital, as well as the trading partner(s) and one's own ability to achieve the goals under the influence of anthropogenic (e.g. institutions, culture and economy) and natural factors (e.g. geographic conditions, climatic changes) from within and outside the SEPL [28, 57, 61, 63-66]. The livelihood strategies people take can consist of resource based (e.g. fishing, farming, forestry, herding) and non-resource based activities (e.g. commerce, public services). The capacities of people, especially in form of local ecological, indigenous or traditional knowledge of the landscape and its ecosystems' dynamics play a crucial role in their pursuit $[35,46,64]$. The knowledge of and access and claims to resources, goods and services remain central determinants for the resilience of SEPLs and for securing the WEF-Nexus for another one billion people $[41,61,63,66]$.

Bringing various stakeholders together on a SEPL scale in an institutionalized way has the advantages of dealing with water, energy and food at once horizontally across the silos, but also vertically across scales (household/community/province). This way deciding, planning and managing the WEF-Nexus in the light of climate change is closer to the rural realities, coincides (more) with the natural systems and the livelihoods of the people, promotes social learning, gives legitimacy, provides mechanisms of conflict resolution, minimizes bias as well as strengthens the factual base and meaningfully integrates the natural and anthropogenic dynamics of the WEF-Nexus [21, 24, 35, 43, 45, 48, 70-73].

\section{Conclusion}

With the high dependence of rural inhabitants on local ecosystems and their services, and thereby the stronger connection to their landscapes, the search for improvements of the Water-Energy-Food Nexus of the one billion underserved should start here. Because the presented approach recognizes the rural reality of livelihood diversity within a SEPL and the underlying reasons for that, policies 
and development efforts can be tailor-made based on local data and existing social capital. It enables communities to participate locally in tackling water, energy and food related issues holistically at the scale that is relevant for them, while national, international or transboundary dimensions can be taken into consideration where necessary (and not the other way around). Clearly, there is a global unity in that water, energy and food are interlinked, but with the SEPLs' different forms of capital, different kinds of ecosystem services and different interlinkages present, consequently various sets of WEF-Nexii co-exist within one country, watershed or region.

\section{Acknowledgements}

The authors thank the Japanese Ministry of Education, Culture, Sports, Science and Technology for supporting the research of Maximilian Spiegelberg and the Graduate School of Global Environmental Studies at Kyoto University through the MEXT scholarship program.

\section{References}

[1] Belair, C., Ichikawa, K., Wong, B.Y. L., \& Mulongoy, K.J. (eds). Sustainable use of biological diversity in socio-ecological production landscapes. Background to the Satoyama Initiative for the benefit of biodiversity and human well-being. Technical Series no. 52. Secretariat of the Convention on Biological Diversity, Montreal, 2010.

[2] Ellis, C.E., Kaplan, J.O., Fuller, D.Q., Vavrus, S., Klein Goldewijk, K. \& Verburg, Peter Used planet: a global history. Proceedings of the National Academy of Sciences, 110 (20), pp. 7978-7985, 2013.

[3] Grober, U., Die Entdeckung der Nachhaltigkeit - Kulturgeschichte eins Begriffs, Verlag Antje Kunstmann GmbH: München, 2010.

[4] Crutzen, P. J., \& Stoermer E. F., The 'Anthropocene'. Global Change Newsletter, 41, p. 17-18, 2000.

[5] Zalasiwicz, J., Waters, C.N., Williams, M., Human bioturbation, and the subterranean landscape of the Anthropocene in Anthropocene. 2014. (In press).

[6] Rockström, J., Steffen, W., Noone, K., Persson, A., Chapin, F.S.III, Lambin, E., Lenton, T.M., Scheffer, M., Folke, C., Schellnhuber, H.J., Nykvist, B., de Wit, C.A., Hughes, T., van der Leeuw, S., Rodhe, H., Sörlin, S., Snyder, P.K.,Costanza, R., Svedin, U., Falkenmark, M., Karlberg, L., Corell, R.W., Fabry, V.J., Hansen, J., Walker, B., Livermann, D., Richardson, K., Crutzen, P., Foley, J., Planetary Boundaries: Exploring the Safe Operating Space for Humanity. Ecology \& Society, 14(2), p. 32, 2009.

[7] Dearing J.A., Wanga, R., Zhang, K., Dyke, J.G., Haberl, H., Hossain, S., Langdon, P.G., Lenton, T.M., Raworth, K., Brown, S., Carstensen, J., Cole, M.J., Cornell, S.E., Dawson, T.P., Doncasterm, C.P., Eigenbrodm, F., Floerke, M., Jeffers, E., Mackay A.W., Nykvist, B. \& Poppy, G., Safe and 
just operating spaces for regional social-ecological systems. Global Environmental Change, 28, pp. 227-238, 2014.

[8] Agnew, C. \& Woodhouse, P., Water Resources and Development, Routledge: Abingdon, 2011.

[9] Hoff, H., Understanding the Nexus. Background Paper for the Bonn 2011 Nexus Conference: The Water, Energy and Food Security Nexus. Stockholm Environment Institute: Stockholm, 2011.

[10] Howells, M., Hermann, S., Welsch, M., Bazilian, M., Segerström, R., Alfstad, T., Gielen, D., Rogner, H., Fischer, G., van Velthuizen, H., Wiberg, D., Young, C., Roehrl, R.A., Mueller, A., Steduto, P. \& Ramma, I., Integrated analysis of climate change, land-use, energy and water strategies. Nature Climate Change, 3, pp. 621-626, 2013.

[11] Food and Agricultural Organization (UNFAO), The State of Food and Agriculture. Food Systems and Nutrition. UNFAO: Rome, 2013.

[12] International Energy Agency (IEA), World Energy Outlook 2013 Factsheet: How will global energy markets evolve to 2035, IEA: Vienna, 2013.

[13] World Economic Forum (WEF), The Water Resources Group Background, Impact and the Way Forward. WEF: Davos, 2012.

[14] United Nations World Water Assessment Programme (UNWWAP), World Water Development Report 2014: Water and Energy. Volume 1. UNESCO: Paris, 2014.

[15] International Renewable Energy Agency (IRENA), REthinking Energy: Towards a new power system. IRENA: Abu Dhabi, 2014.

[16] FAO, State of the Worlds Land and Water Resources for Food and Agriculture - Managing Systems at Risk. FAO: Rome, 2011.

[17] United Nations Department of Economic and Social Affairs (UNDESA), World Population Policies 2013. UNDESA: New York, 2013.

[18] Intergovernmental Panel on Climate Change (IPCC), Annex 1: Atlas of Global and Regional Climate Projections. Cambridge University Press: Cambridge and New York City, 2014.

[19] United Nations Non-Governmental Liaison Service (UNNGLS), Civil society engagement in the post-2015 development agenda negotiations. New York City.

[20] Brodizio, E.S., Ostrom, E. \& Young, O.R., Connectivity and the Governance of Multilevel Social-Ecological Systems: The Role of Social Capital. Annual Review of Environment and Resources, 34, pp. 253-278, 2009.

[21] Duraiappah, A.K., Asah, S.T., Brondzio, E.S., Kosoy, N., O’Farell, P.J., Prieur-Richard, A-H., Subramanian, S.M. \& Takeuchi, K., Managing the Mismatches to Provide Ecosystem Services for Human Well-being: A Conceptual framework for understanding the New Commons. Current Opinion in Environmental Sustainability, 7, pp. 94-100, 2014.

[22] Loevinsohn, M., Mehta, L., Cuming, K., Nicol, A., Cumming, O. \& Ensink, J.H.J., The cost of a knowledge silo: a systematic re-review of water, sanitation and hygiene interventions. Health Policy and Planning 2014, pp. $1-15,2014$. 
[23] Bazilian, M., Rogner, H., Howells, M., Hermann, S., Arent, D., Gielen, D., Steduto, P., Mueller, A., Komor, P., Tol, R., Yumkellah, K. K., Considering the energy, water and food nexus: Towards an integrated modeling approach. Energy Policy, 39 (12), pp. 7896-7906, 2011.

[24] Bizikova, L., Dimple, R., Swansen, D., Venema, H.D. \& McCandless, M., The Water-Energy-Food Security Nexus: Towards a practical planning and decision-support framework for landscape investment and risk management. IISD Report February 2013, International Institute for Sustainable Development: Manitoba, 2013.

[25] Homer-Dixon, T., Environmental Scarcities and Violent Conflict: Evidence from Cases. International Security, 19 (1), pp. 5-40, 1994.

[26] Koppen, B. van, Smits, S., Moriarty, P., Penning de Vries, F., Mikhail, M. \& Boelee, E., Climbing the Water Ladder - multiple-use water services for poverty reduction. TP series, no. 52, IRC International Water and Sanitation Centre and International Water Management Institute: The Hague, 2009.

[27] Practical Action, Poor people's energy outlook 2012: Energy for earning a living. Practical Action Publishing: Rugby, 2012.

[28] Whitfield, S. \& Reed, M.S., Participatory environmental assessment in drylands: Introducing a new approach. Journal of Arid Environment, 77, pp. $1-10,2012$.

[29] FAO, The Water-Energy-Food Nexus at FAO - A Concept Note. FAO, Rome, 2014.

[30] Granit, J., Fogde, M., Hoff, H., Joyce, J., Karlberg, L., Kuylenstierna, J. \& Rosemarin, A. Unpacking the Water-Energy-Food Nexus: Tools for Assessment and Cooperation Along a Continuum. (Chapter 8). Cooperation for a Water Wise World - Partnerships for Sustainable Development, eds. A. Jägerskog, T.J. Clausen, K. Lexén, T. Holmgren, Stockholm International Water Institute: Stockholm, Report Nr. 32, pp. 45-50, 2013.

[31] Lawford, R., Bogardi, J., Marx, S., Jain, S., Pahl-Wostl, C., Knüppe, K., Ringler, C., Lansigan, F. \& Meza, F., Basin perspectives on the WaterEnergy-Food Security Nexus. Current Opinion in Environmental Sustainability, 5, pp. 607-616, 2013.

[32] Millennium Ecosystem Assessment. Ecosystems and Human Well-Being. United Nations Environment Programme: Nairobi, 2005.

[33] Practical Action, Poor people's energy outlook 2013: Energy community services. Practical Action Publishing: Rugby, 2013.

[34] Adeel, Z., Schuster, B. \& Bigas, H., What Makes Traditional Technologies Tick? A Review of Traditional Approaches for Water Management in Drylands. United Nations University - International Network on Water, Environment and Health (UNU-INWEH): Tokyo, 2008.

[35] United Nations University - Institute for the Advanced Study of Sustainability (UNU-IAS), Bioversity International, IGES \& UNDP, Toolkit for the Indicators of Resilience in Socio-ecological Production Landscapes and Seascapes (SEPLS). UNU-IAS: Yokohama, 2014.

[36] Head, L., Conceptualising the human in cultural landscapes and resilience thinking. (Chapter 4). Resilience and the Cultural Landscape: 
Understanding and Managing Change in Human-shaped Environments, eds. T. Plieninger \& C. Bieling. Cambridge University Press, Cambridge, pp. 65-79, 2012.

[37] Reed, M.S., Fazey, I., Stringer, L.C., Raymond, C.M., Akhtar-Schuster M., Begni, G., Bigas, H., Brehm, S., Briggs, J., Bryce, R., Buckmaster, S., Chanda, R., Davies, J., Diez, E., Essahli, W., Evely, A., Geeson, N., Hartmann, I., Holden, J., Hubacek, K., Ioris, A. A. R., Kruger, B. Laureano, P., Phillipson, J., Prell, C., Quinn, C. H., Reeves, A. D., Seely, M., Thomas, R., Werff Ten Bosch, M. J. van der, Vergunst, P. \& Wagner, L., Knowledge Management for Land Degradation Monitoring and Assessment: An Analysis of Contemporary Thinking. Land Degradation \& Development, 24, pp. 307-322, 2013.

[38] Saslis-Lagoudakis, C. H, Hawkins, J.A., Greenhill, S.J., Pendry, C.A., Watson, M.F., Tuladhar-Douglas, W., Baral, S.R., Savolainen, V., The evolution of traditional knowledge: environment shapes medicinal plant use in Nepal. Proceedings of the Royal Society B: Biological Sciences, 281 (1780), 2014.

[39] Shiva, V., Monocultures of the Mind. The Trumpeter-Journal of Ecosophy, 10 (4), 1993.

[40] Walshe, R. \& Argumedo, A., The elephant in the room: policy based responses to climate change are still failing to account for indigenous voices. Climate Exchange Org.: Norwich, 2014. http://climate-exchange. org/2014/08/01/the-elephant-in-the-room-policy-based-responses-toclimate-change-are-still-failing-to-account-for-indigenous-voices/.

[41] FAO. Mainstreaming Climate-Smart Agriculture into a broader Landscape Approach. FAO: Rome, 2012.

[42] Carius, A., Dabelko, G.D. \& Wolf, A.T., Water, Conflict, and Cooperation. Woodrow Wilson Center: Washington DC, 2004. http://www.wilsoncenter.org/sites/default/files/ecspr10_unf-caribelko.pdf.

[43] International Union for the Conservation of Nature (IUCN), Water and Nature Initiative: WANI-2 Final Report. IUCN: Gland, 2012.

[44] Ostrom, E., Governing the commons. The evolution of institutions for collective action. Cambridge University Press: Cambridge: 1990 (20 ${ }^{\text {th }}$ ed.).

[45] Callo-Concha, D., Approaches to managing disturbance and change: Resilience, vulnerability and adaptability. ZEF Working Paper 133, Zentrum für Entwicklungsforschung: Bonn, 2014.

[46] Cundil, G., Shackleton, S., Sisitka, L., Ntshudu, M., Lotz-Sisitka, H., Kulundu, I. \& Hamer, N., Social learning for adaptation: a descriptive handbook for practitioners and action researchers. IDRC \& Rhodes University \& Ruliv: Grahamstown, 2014.

[47] Regmi, B.R., Morcrette, A., Paudyal, A., Bastakoti, R. \& Pradhan, S. Participatory Tools and Techniques for Assessing Climate Change Impacts and Exploring Adaptation Options - A Community Based Tool Kit for Practitioners. Livelihood and Forestry Programme: Nepal, 2010.

[48] Wilson, G.A., Community Resilience, Transitional Corridors and MacroScalar Lock-in Effects. Environmental Policy \& Governance, 23 (6), 2013. 
[49] Venton, P., Drought Risk Management: Practitioner's Perspectives from Africa and Asia. UNDP: New York City, 2012.

[50] FAO, The State of Food and Agriculture. Innovation in family farming. FAO: Rome, 2012.

[51] Reed, M.S., Podesta, G., Fazey, I., Geeson N., Hessel R., Hubacek K., Letson, D., Nainggolan, D., Prell C. \& Rickenbach, M.G., Combining analytical frameworks to assess livelihood vulnerability to climate change and analyse adaptation options. Ecological Economics, 94, pp. 66-77, 2013.

[52] Wilson, G. \& Abbott, D. Climate change: lived experience, policy and public action International Journal of climate Change Strategies and Management, 6 (1), pp. 5-18, 2014.

[53] Asian Development Bank (ADB), Thinking about Water differently Managing the Water-Food-Energy Nexus. ADB: Bangkok, 2013.

[54] Bapna, M., 4 Grand Challenges to Energy, Food, \& Water. World Resource Institute: Washington DC, 2013. http://www.wri.org/blog/4-grandchallenges-energy-food-and-water.

[55] Beck, M. \& Walker, V., On water security, sustainability, and the waterfood-energy-climate nexus. Frontier of Environmental Science \& Engineering, 7 (5), pp. 626-639, 2013.

[56] Future Earth, Strategic Research Agenda. Priorities for a global sustainability research strategy. ICSU: Paris, 2014.

[57] Krchnak, K.K., Smith, M.D. \& Deutz A., Putting Nature in the Nexus. Investing in Natural Infrastructure to Advance Water-Energy-Food Security. IUCN \& The Nature Conservancy: Gland \& Washington DC, 2011.

[58] Middleton, C. \& Allen, S., The (re)discovery of "the Nexus": Political economies and dynamic sustainabilities of water, energy and food security in Southeast Asia. Proc. of the Conf. Transforming Societies: Contestations and Convergences in Asia and the Pacific. Asia Pacific Sociological Association (APSA): Chiang Mai, 2014.

[59] Smajgl, A. \& Ward, J., The Water Energy Food Nexus in the Mekong Region: Assessing Development Strategies Considering Cross-Sectoral and Transboundary Impacts. Springer Science+Business Media: New York City, 2013.

[60] United Nations Economic and Social Commission for Asia \& Pacific (UNESCAP). The Status of the Water-Food-Energy Nexus in Asia and the Pacific. UNESCAP: Bangkok, 2013.

[61] Lele, U., Klousia-Marquis, M. \& Goswami, S. Good governance for food, water and energy security. Aquatic Procedia, 1, pp. 44-63, 2013.

[62] International Fund for Agricultural Development (IFAD), Rural Poverty Report 2011. IFAD: Rome, 2010.

[63] Gunderson, L., Kinzig, A., Quinlan, A., Walker, B., Cundhill, G., Beier, C., Crona, B. \& Bodin, Ö., Assessing Resilience in Social-Ecological Systems: Workbook for Practitioners. (Revised Version 2.0) Resilience Alliance: Stockholm, 2010. 
[64] Sayer, J., Sunderland, T., Ghazoul, J., Pfund, J.-L., Sheil, D., Meijaard, E., Venter, M., Boedhihartono, A.K., Day, M., Garcia C., van Oosten, C., \& Buck, L.E. Ten principles for a landscape approach to reconciling agriculture, conservation and other competing land uses. Proceedings of the National Academy of Sciences, 110 (21), pp. 8349-8356, 2013.

[65] Scherr, S. J., Shames S. \& Friedman R., Defining integrated landscape management for policy makers. Ecoagriculture Policy Focus No. 10, EcoAgriculture Partners: Washington DC, 2013.

[66] Chambers, R. \& Conway, G.R., Sustainable rural livelihoods: practical concepts for the $21^{\text {st }}$ century. Institute for Development Studies (IDS) Discussion Paper 296, IDS: Brighton, 1992.

[67] Morse, S. \& McNamara, N., Sustainable Livelihood Approach. A critique of Theory and Practice. Springer: Heidelberg, 2013.

[68] Sherbinin, A.de, VanWey, L.K., McSweeney, K., Aggarwal, R., Barbieri, A., Henry, S., Hunter, L.M., Twine, W. \& Walker, R., Rural household demographics, livelihood and the environment. Global Environmental Change, 18, pp. 38-53, 2008.

[69] Walker, B., Holling, C.S., Carpenter, S.R. \& Kinzig, A., Resilience, Adaptability and Transformability in Social-ecological Systems. Ecology and Society, 9 (2), Art.5, 2004.

[70] Gyampoh, B.A., Idinoba, M. \& Ndi Nkem, J., Using traditional knowledge to cope with climate change in rural Ghana. Unasylva, 60 (231/232), 2009/1-2 FAO: Rome, 2009.

[71] Kirchhoff, T., Brand, F.S. \& Hoheisel, D., From cultural landscapes to resilient socio-ecological systems: transformation of a classical paradigm or a novel approach. (Chapter 3) Resilience and the Cultural Landscape: Understanding and Managing Change in Human-shaped Environments. eds T. Plieninger \& C. Bieling, Cambridge University Press, Cambridge, pp. 49-64, 2012.

[72] Plieninger, T., Bieling, C., Ohnesorge, B., Schaich, H., Schleyer, C. and Wolff, F., Exploring futures of ecosystem services in cultural landscapes through participatory scenario development in the Swabian Alb. Germany. Ecology and Society, 18(3), p. 39, 2013.

[73] Zimmerer, K.S., Conserving agrobiodiversity amid global change, migration, and nontraditional livelihood networks: the dynamic uses of cultural landscape knowledge. Ecology and Society, 19 (2), 2014. 